\title{
Pengembangan Potensi Desa Jembayan Tengah Sebagai Agrowisata di Kecamatan Loa Kulu Kabupaten Kutai Kartanegara
}

\author{
Sabalius Uhai* \\ Usaha Perjalanan Wisata, Politeknik \\ Negeri Samarinda, Samarinda, \\ 75131 \\ sabaliusuhai@polnes.ac.id \\ *Corresponding author
}

\author{
Rini Koen Iswandari \\ Usaha Perjalanan Wisata, Politeknik \\ Negeri Samarinda, Samarinda, \\ 75131 \\ Rini02@polnes.ac.id
}

\author{
I Wayan Sudarmayasa \\ Pariwisata, Politeknik Negeri \\ Samarinda, Samarinda, 75131 \\ i_w_sudarmayasa@polnes.ac.id
}

\author{
I Made Adhi Gunadi \\ Fakultas Pariwisata, Universitas Pancasila, Srengseng \\ Sawah, Jagakarsa, Jakarta 12640 \\ made.gunadi@univpancasila.ac.id
}

\author{
Egi Saltia Anggriawan \\ Usaha Perjalanan Wisata, Politeknik Negeri Samarinda, \\ Samarinda, 75131 \\ egisaltia@gmail.com
}

\begin{abstract}
Abstrak-Penelitian ini dilatarbelakangi oleh rasa ingin tahu tentang potensi wisata yang ada di Desa Jembayan Tengah dengan diketahuinya potensi yang ada di Desa Jembayan Tengah sehingga para pengelola obyek dan daya tarik wisata yakni Kelompok Sadar Wisata dapat melakukan pengembangan wisata sehingga layak untuk dikunjungi oleh para pengunjung. Oleh karena itu tujuan dari penelitian ini adalah untuk mengetahui potensi wisata yang ada di Desa Wisata Jembayan Tengah. Metode yang digunakan dalam penelitian ini adalah metode wawancara secara mendalam dan dilakukan analisis deskriptif kualitif . Hasil penelitian ini menunjukan bahwa Desa Jembayan Tengah Layak dikembangkan menjadi sebuah desa wisata dengan berbasis agrowisata.
\end{abstract}

Kata Kunci-Pengembangan potensi desa, potensi wisata, desa wisata, agrowisata, Desa Jembayan Tengah

\section{I.PENDAHULUAN}

Desa Jembayan Tengah adalah sebuah desa yang berada di Kecamatan Loa Kulu Kabupaten Kutai Kartanegara Kalimantan Timur. Desa Jembayan Tengah memiliki potensi agrowisata berupa hasil pertanian yakni padi, bawang prei, bawang rambut, singkong yang memiliki ukuran besar dimana dalam bahasa lokal disebut dengan singkong selingkuh, penamaan singkong selingkuh karena hasil kawin silang antara singkong gajah dan singkong karet. Potensi yang sangat melimpah ini masih belum dimanfaatkan dan dikembangkan oleh masyarakat setempat sampai saat ini. Kurangnya kesadaran masyarakat untuk membuat suatu wisata membuat segala potensi yang ada menjadi kurang berkembang. Dibutuhkan gertakan perubahan untuk menciptakan kesadaran masyarakat setempat untuk mengembangkan potensi yang ada. Karena seperti yang kita tahu bahwa suatu kawasan dengan pengelolaan pariwisata yang baik menciptakan berbagai perkembangan kemajuan di segala aspek kehidupan di daerah tersebut (Ayu, 2020). namun baik masyarakat maupun pengelola destinasi belum terlihat menyadari benar potensi tersebut sehingga penanganan desa yang memenuhi karakteristik sebagai desa wisata tidak dilakukan dengan semestinya (Susyanti, D. W., \& Latianingsih, 2015), oleh karena itu diperlukan sebuah strategi dalam usaha mengembangkan desa wisata (Pantiyasa, 2018). Pengembangan potensi desa wisata melalui pelatihan (Sembiring, V. A., Widyastuti, N., Mustika, 2019), (Sembiring, V. A., Taviprawati, E., Darsiah, 2020). Peningkatan kapasitas kelompok penggerak pariwisata di desa (Ingkadijaya, R., Ratu Bilqis, 2020), (Suprina, R., Pasaribu, P., Rachmatullah, 2020).

Wisata merupakan kegiatan yang hampir semua orang pernah lakukan, bahkan tidak sedikit yang sangat menggemari kegiatan tersebut. Wisata berarti bepergian bersama-sama dan lebih diidentikkan dengan pergi keluar atau tamasya (Chairunnisa, L. Sari, W. E. Arifin, 2020). Pariwisata adalah kegiatan dinamis yang melibatkan banyak manusia serta menghidupkan berbagai bidang usaha. Indonesia adalah salah satu Negara yang memiliki potensi pariwisata yang sangat besar, ditunjang dengan kondisi geografis dan warisan budayanya. Pariwisata di Indonesia merupakan sektor ekonomi penting di Indonesia (Mahriani, 2020). Pergerakan wisatawan dunia dan nasional pada saat ini sudah semakin tinggi. Hal tersebut menyebabkan permintaan terhadap bisnis pariwisata yang semakin meningkat. Permintaan tersebut telah menyebabkan menjamurnya bisnis pariwisata yang menyediakan berbagai macam usaha, mulai dari usaha yang berbasis alam, acara (event), budaya atau buatan. Fenomena tersebut telah memperlihatkan tingkat persaingan bisnis pariwisata yang semakin ketat(Srisusilawati, 2020). 
Indonesia khususnya Kalimantan Timur yakni di Desa Jembayan Tengah Kecamatan Loa Kulu Kabupaten Kutai Kartanegara, desa ini memiliki jarak 19 kilometer dari pusat kota Tenggarong dan 45 kilometer dari pusat kota Samarinda. Desa Jembayan Tengah memiliki masyarakat yang mayoritas bekerja di bidang pertanian, perkebunan, peternakan dan perikanan yang berpotensi untuk dijadikan Agrowisata Bahari, Bahari dalam bahasa kutai adalah "lama", maksud di atas mengartikan bahwa segala kegiatan pertanian, perkebunan, perikanan, dan peternakan dilakukan dengan menggunakan cara lama atau manual. Dengan menggunakan sistem tradisional yang digunakan oleh masyarakat Desa Jembayan Tengah dapat menjadi daya tarik bagi pengunjung. Para pengunjung dapat terlibat langsung dalam kegiatan petani, misalnya mencabut singkong selingkuh, ke kebun daun bawang dan bawang prei.

Berdasarkan latar belakang diatas, maka dapat diambil suatu permasalahan yang terkait mengenai potensi wisata yang ada di Desa Jembayan Tengah adalah Bagaimana pengembangan potensi desa Jembayan Tengah sebagai agrowisata di Kecamatan Loa Kulu Kabupaten Kutai Kartanegara?

\section{II.TINJAUAN PUSTAKA}

\subsection{Jenis Dan Macam Pariwisata}

Sesuai dengan potensi yang dimiliki atau warisan yang ditinggalkan nenek moyang pada suatu negara, maka timbullah bermacam-macam jenis dan macam pariwisata yang dikembangkan sebagai kegiatan, yang lama kelamaan mempunyai cirinya tersendiri. Untuk keperluan perencanaan dan pengembangan kepariwisataan itu sendiri, perlu pula dibedakan antara pariwisata dengan jenis pariwisata lainnya, Karena dengan demikian akan dapat ditentukan kebijaksanaan apa yang perlu mendukung, sehingga jenis dan macam pariwisata yang dikembangkan akan dapat berwujud seperti diharapkan dari kepariwisataan itu (Srisusilawati. 2020).

Ditinjau dari segi ekonomi, pemberian klasifikasi tentang jenis pariwisata itu dianggap penting, Karena dengan cara itu kita akan dapat menentukan beberapa penghasilan devisa yang diterima dari suatu dari suatu macam pariwisata yang dikembangkan disuatu tempat atau daerah tertentu (Yoeti, 1996)

2.1.1 Jenis Pariwisata Menurut Alasan/ tujuan perjalanan 2.1.2.1 Business Tourism

Yaitu jenis pariwisata dimana pengunjungnya datang untuk tujuan dinas, usaha dagang atau yang berhubungan dengan pekerjaannya, kongres, seminar, convention, symposium, musyawarah kerja.

2.1.2.2 Vocational Tourism

Yaitu jenis pariwisata dimana orang-orang yang melakukan perjalanan wisata terdiri dari orang-orang yang sedang berlibur, cuti atau pakansi (Yoeti, 1996).

\subsubsection{Education Tourism}

Yaitu jenis pariwisata dimana pengunjung atau orang melakukan perjalanan untuk tujuan studi atau mempelajari suatu bidang ilmu pengetahuan. Termasuk kedalamnya adalah dharmawisata (study-tour). Dalam bidang bahasa dikenalistilah "polly glotisch" yaitu meningkatkan kemampuan berbahasa asing, seseorang memerlukan tinggal untuk sementara waktu di negara yan bahasanya sedang dipelajari (agar lebih dapat menghayatinya) (Yoeti, 1996).

\subsubsection{Objek Dan Atraksi Wisata}

Dalam litertur kepariwisataan luar negeri tidak dijumpai istilah objek wisata seperti yang biasa dikenal di Indonesia. Untuk pengertian objek wisata mereka lebih banyak menggunakan istilah "tourist attraction" yaitu segala sesuatu yang menjadi daya tarik bagi orang untuk mengunjungi suatu daerah tertentu (Yoeti, 1996).

Menurut Peraturan Pemerintah No.24/1979 mejelaskan bahwa objek wisata adalah perwujudan daripada ciptaan manusia, tata hidup, seni budaya serta sejarah bangsa dan tempat atau keadaan alam yang mempunyai daya tarik untuk dikunjungi wisatawan, sedangkan menurut Surat Keputusann Departemen Pariwisata, Pos, dan Telekomunikasi No.KM 98/PW:102/MPPT-87 Objek Wisata adalah tempat atau keadaan alam yang memiliki sumber daya wisata yang dibangun dan di kembangkan sehingga mempunyai daya tarik dan diusahakan sebagai tempat yang dikunjungi wisatawan.

Adapun syarat yang harus dimiliki agar daerah tersebut menarik untuk dikunjungi yaitu:

a) Daerah itu harus mempunyai apa yang disebut sebagai "something to see". Artinya ditempat tersebut harus ada objek wisata dan atraksi wisata, yang berbeda dengan apa yang dimiliki oleh daerah lain. Dengan kata lain daerah itu harus mempunyai daya tarik khusus dan atraksi wisata yang dapat dijadikan sebagai "entertaiments" bila orang datang kesana.

b) Daerah itu harus tersedia apa yang disebut dengan istilah "something to do". Artinya, di tempat tersebut selain banyak yang dapat dilihat dan disaksikan, harus pula disediakan fasilitas rekreasi atau amusements yang dapat membuat mereka betah tinggal lama lebih lama di tempat itu.

c) Daerah itu harus tersedia apa yang disebut dengan istilah "something to buy" artinya ditempat tesebut harus tersedia fasilitas untuk berbelanja (shopping), terutama barang barang souvernir dan kerjinan rakyat sebagai oleh-oleh untuk dibawa pulang ketempat asal masing-masing (Yoeti, 1996).

2.1.3 Daerah Tujuan Wisata

Unsur pokok yang harus mendapat perhatian guna menunjang pengembangan pariwisata di daerah tujuan wisata yang menyangkut perencanaan, pelaksanaan pembangunan dan pengembangan meliputi 5 unsur (Suawantoro, 1997):

1. Objek dan daya tarik wisata,

2. Prasarana wisata,

3. Sarana wisata,

4. Tata laksana/ infrastruktur

5. Masyarakat/lingkungan.

Dalam Udang-Undang No.10 Tahun 2009 disebutkan bahwa Daerah tujuan pariwisata yang selanjutnya disebut Destinasi Pariwisata adalah kawasan geografis yang berada dalam satu atau lebih wilayah administratif yang di dalamnya terdapat daya tarik wisata, 
fasilitas umum, fasilitas pariwisata, aksesibilitas, serta masyarakat yang saling terkait dan melengkapi terwujudnya kepariwisataan.

\subsubsection{Objek dan Daya Tarik Wisata}

Dalam Undang-Undang No.10 Tahun 2009 disebutkan bahwa Daya Tarik Wisata adalah segala sesuatu yang memiliki keunikan, keindahan, dan nilai yang berupa keanekaragaman kekayaan alam, budaya, dan hasil buatan manusia yang menjadi sasaran atau tujuan kunjungan wisatawan.

Daya tarik wisata yang juga disebut objek wisata merupakan potensi yang menjadi pendorong kehadiran wisatawan ke suatu daerah tujuan wisata(Suawantoro, 1997).

a. Pengusahaan objek dan daya tarik wisata dikelompokan kedalam:

1. Pengusahaan objek dan daya tarik wisata alam,

2. Pengusahaan objek dan daya tarik wisata budaya,

3. Pengusahaan objek dan daya tarik wisata minat khusus.

Dalam kedudukannya yang sangat menentukan itu maka daya tarik wisata harus dirancang dan dibangun/ dikelola secara professional hingga dapat menarik wisatawan untuk datang. Membangun suatu objek wisata harus dirancang sedemikian rupa berdasarkan kriteria tertentu.

b. Umumnya daya tarik suatu objek wisata berdasarkan pada:

1. Adanya sumber daya yang dapat menimbulkan rasa senang, indah, nyaman dan bersih.

2. Adanya aksebilitas yang tinggi untuk dapat mengunjunya.

3. Adanya ciri khusus/spesifikasi yang bersifat langka.

4. Adanya sarana/ prasarana penunjang untuk melayani para wisatawan.

5. Objek wisata alam mempunyai daya tarik tinggi karena keindahan alam pegunungan, sungai, pantai, pasir, hutan, dan sebagainya.

6. Objek wisata budaya mempunyai daya tarik tinggi karena memiliki nilai khusus dalam bentuk atraksi kesenian, upacara -upacara adat, nili luhur yang terkandung dalam suatu objek buah karya manusia pada masa lampau.

c. Pembangunan suatu objek wisata harus dirancang dengan sumber pada potensi daya tarik yang dimiliki objek tersebut dengan mengacu pada kriteria keberhasilan pengembangan yang meliputi berbagai kelayakan sebagai berikut:

\subsubsection{Prasarana Wisata}

Prasarana wisata adalah sumber daya alam dan sumber daya buatan manusia yang mutlak dibutuhkan oleh wisatawan dalam perjalanannya di daerah tujuan wisata, seperti jalan, listrik air, telekomunikasi, terminal, jembatan dan lain sebagainya. Untuk kesiapan objekobjek wisata yang akan dikunjungungi oleh wisatawan daerah tujuan wisata, prasarana wisata tersebut perlu dibangun dengan disesuaikan dengan lokasi dan kondisi objek wisata yang bersangkutan (Suawantoro, 1997).
Prasarana pariwisata adalah sumber daya alam dan sumber daya manusia yang mutlak dibutuhkan oleh wisatawan dalam perjalanannya di daerah tujuan wisata, seperti jalan, listrik, air, telekomunikasi, terminal, jembatan, dan lain sebagainya (Ghani, 2017).

1. Aksesibilitas

Aksesibilitas merupakan daya hubungan antara zona yang wujudnya berupa jalan raya dan jaringan angkutan. Aksesibilitas merupakan faktor penting dalam proses berwisata, tingkat kemudahan untuk menjangkau suatu kawasan wisata dilihat dari aksesibilitas yang berupa kondisi jalan raya, ketersediaan moda angkutan untuk menuju kawasan wisata tersebut. Peningkatan aksesibilitas berarti mempersingkat waktu dan biaya perjalanan.

2. Utilitas

Yang termasuk kelompok utilitas adalah :

a. Listrik ketersediaan sumber energi listrik adalah prasyarat bagi pengembangan industri pariwisata. Tetapi harus diperhatikan penggunaanya. Tidak semua kawasan wisata membutuhkan listrik, atau hanya membutuhkan sedikit energi listrik.

b. Air bersih

c. Persediaan air minum

d. Toilet

e. Mushola

3. Jaringan pelayanan

a. Pelayanan kesehatan dalam bentuk pos kesehatan atau persediaan P3K

b. Keamanan, dalam bentuk Pos keamanan beserta pihak keamanan atau oknum petugas, agar terhindar dari tindakantindakan kriminal selama berada di kawasan wisata.

\subsubsection{Sarana Wisata}

Sarana wisata yang merupakan kelengkapan daerah tujuan wisata yang diperlukan untuk melayani kebutuhan wisatawan dalam menikmati perjalanan wisatanya. Pembangunan sarana wisata daerah tujuan wisata maupun objek wisata tertentu harus di sesuaikan dengan kebutuhan wisatawan baik secara kuantitatif maupun kualitatif. Lebih dari itu selera pasar pun dapat menentukan tuntutan sarana yang dimaksud. Berbagai sarana wisata yang harus di sediakan di daerah tujuan wisata ialah hotel, biro perjalanan, alat transportasi, restoran dan rumah makan serta pendukung lainnya. Tak semua objek wisata memerlukan sarana memerlukan sarana yang sama atau lengkap. Pengadaan sarana wisata tersebut harus disesuaikan dengan kebutuhan wisatawan (Suawantoro, 1997). Sarana kepariwisataan dibagi menjadi tiga kelompok (Ghani, 2017), diantaranya:

1. Sarana pokok (main tourism superstructure)

Sarana pokok kepariwisataan adalah perusahaan yang hidup dan kehidupannya sangat tergantung kepada kedatangan orang yang melakukan perjalanan wisata. Yang termasuk ke dalam kelompok ini adalah Travel agent, Tour operator, Angkutan wisata, Rumah makan, Akomodasi, Objek wisata dan Atraksi wisata. 
2. Sarana Pelengkap Kepariwisataan (Suplementing Tourism Superstructure)

Yaitu perusahaan-perusahaan atau tempat-tempat yang menyediakan fasilitas untuk rekreasi yang fungsinya tidak hanya melengkapi sarana pokok kepariwisataan dapat lebih lama tinggal pada suatu daerah tujuan wisata. Yang termasuk ke dalam kelompok ini adalah: Sarana Olahraga, Sarana pariwisata sekunder, dan amusement lainnya.

3. Sarana Penunjang Kepariwisataan (Supporting Tourism Superstructure)

Sarana pelengkap dan sarana pokok dan berfungsi tidak hanya membuat wisatawan lebih lama tinggal pada suatu daerah tujuan wisata, tetapi memiliki fungsi lain yaitu, membuat wisatawan atau pengunjung daerah tujuan wisata lebih banyak mengeluarkan dan membelanjakan uangnya di tempat tujuan wisata yang mereka kunjungi.

\subsubsection{Pengertian Agrowiata}

Selama ini agrowisata merupakan produk yang belum banyak dimanfaatkan oleh kalangan usaha perjalanan. Padahal minat wisatawan terhadap kegiatan agrowisata cukup besar, terutama wisatawan mancanegara. Namun belakangan ini agrowisata sebagai salah satu potensi wisata yang mulai ditawarkan kepada wisatawan (Susyanti dan Latianingsih, 2015). Pengembangan agrowisata merupakan upaya terhadap pemanfaatan atraksi wisata pertanian. Berdasarkan surat keputusan (SK) Bersama Mentri Pariwisata, Pos, dan Telekomunikasi (Menparpostel) dan Mentri Pertanian No. KM.47/PW.DOW/MPPT-89 dan No. 204/KPTS/HK/050/4/1989, agrowisata sebagai bagian dari objek wisata diartikan sebagai suatu bentuk kegiatan yang memanfaatkan usaha agro sebagai objek wisata dang tujuan untuk untuk memperluas pengetahuan, pengalaman rekreasi, dan hubungan usaha dibidang pertanian. Agrowisata telah diberi Batasan sebagai wisata yang memanfaatkan obyek-obyek pertanian(Tirtawinata, R., 1996) .

\subsubsection{Perkebunan}

Kegiatan usaha perkebunan meliputi perkebunan tanaman keras dan tanaman lainnya yang dilakukan oleh perkebunan besar swasta. Nasional ataupun asing, BUMN, dan pekebunan rakyat. Berbagai kegiatan obyek wisata perkebunan dapat berupa praproduksi (pembibitan), produksi, dan pascaproduksi (pengolahan dan pemasaran).

Daya tarik perkebunan sebagai sumber daya wiata antara lain: (Fachrudin,1996:4)

a. Daya tarik historis dari perkebunan yang sudah diusahakan sejak lama,

b. Lokasi beberapa wilayah perkebunan yang terletak di peguunan yang memberikn pemandangan indah serta berhawa segar,

c. Cara-cara tradisional dalam pola tanam, pemeliharaan, pengelolaan dan prosesnya, serta

d. Perkembangan Teknik pengelolaan yang ada.

2.1.5 Tanaman Pangan dan Hortikultura

Lingkup kegiatan wisata tanaman pangan yang meliputi usaha tanaman padi dan palawija serta hortikultura yskni bunga, buah sayur, dan jamu-jamuan. Berbagai proses kegiatan mulai dari prapanen, pascapanen berupa pengolahan hasil, sampai kegiatan pemasarannya dapat dijadikan objek agrowisata. (Tirtawinata, R., 1996)

\subsubsection{Peternakan}

Daya tarik peternakan sebagai sumber daya wisata antara lain pola beternak, cara tradisional dalam peternakan, serta budi daya hewan ternak.

\subsubsection{Perikanan}

Ruang Lingkup kegiatan Wisata perikanan dapat berupa kegiatan budi daya perikanan sampai proses pascapanen. Daya tarik perikanan sebagai sumber daya wisata di antaranya pola tradisional dalam perikanan serta kegiatan lain, misalnya memancing ikan.

2.2 Manfaat Agrowisata

Adapun manfaat agrowisata menurut Tirtawinata, Fachrudin (Tirtawinata, R., 1996) anatara lain:

1. Meningkatkan Konservasi Lingkungan

2. Meningkatkan Nilai Estetika dan Keindahan Alam

3. Memberikan Nilai Rekreasi

4. Meningkatkan Kegiatan Ilmiah dan Pengembangan Ilmu Pengetahuan

5. Mendapatkan Keuntungan Ekonomi

\section{III.METODE PENELITIAN}

A. Tempat dan Waktu

Penelitian ini dilaksanakan di Desa Jembayan Tengah Kecamatan Loa Kulu Kabupaten Kutai Kartanegara Kalimantan Timur. Penelitian ini dilakukan pada bulan maret 2020 sampai dengan april 2020.

B. Alat dan Bahan

1. Alat

Alat yang digunakan adalah:

a. Laptop

b. Kamera

c. Buku catatan

2. Bahan

a. Potensi yang ada di Desa Jembayan tengah.

C. Prosedur Penelitian

1. Pengumpulan data

a. Wawancara

Wawancara yaitu pengumpulan data dengan cara tanya jawab secara lansung kepada pihak-pihak yang terlibat dalam objek penelitian. Dalam mendapatkan data ini penulis menanyakan informasi tentang Desa Jembayan Tengah. Namun pada pembahsan penulis akan melakukan wawancara langsung kepada beberapa masyarakat ataupun petani.

b. Observasi

Observasi adalah metode pengumpulan data melalui pengamatan atau peninjauan secara langsung di lokasi penelitian. Teknik pengumpulan data dengan observasi digunakan bila penelitian berkenaan dengan perilaku manusia, proses kerja, gejalagejala alam dan bila responden yang diamati tidak terlalu besar. 
c. Studi Pustaka

Studi pustaka adalah teknik pengumpulan data dengan mengadakan studi, referensi, dari berbagai buku-buku dan laporan-laporan yang berhubungan dengan penelitian

2. Sumber data

a. Data Primer

Data Primer yaitu data yang diperoleh secara langsung dari lokasi penelitian seperti wawancara, observasi yang dapat dimanfaatkan untuk mengetahui potensi di Desa Jembayan Tengah.

b. Data Sekunder

Data Sekunder yaitu data yang dikumpulkan selain dari tempat atau objek penelitian. Penulis memperoleh data dari dokumen-dokumen di Desa Jembayan Tengah dan sumber-sumber lain .

3. Analisis Masalah

Teknik penelitian yang diterapkan dalam penelitian ini adalah analisis deskriptip yaitu teknik mencari data yang digunakan untuk mendapatkan gambaran keseluruhan objek yang diteliti dan dengan pengamatan mengenai segala potensi yang ada di Desa Jembayan Tengah. Dengan cara menguraikan pokok bahasan dalam pembahasan ini yaitu potensi agrowisata di desa jembayan tengah.

\section{IV.HASIL DAN PEMBAHASAN}

\section{A. Profil Desa Jembayan}

Desa Jembayan Tengah dikenal dengan sebutan Kampong Seraong karena di desa ini banyak sekali kita jumpai di rumah-rumah warga mengelola daun kadang menjadi produk kerajian sebagai mata pencaharian mereka. Cikal bakal Desa Jembayan Tengah adalah Kampung Silingsing, awal mula Kampung Silingsing adalah hutan rimba yang luas dari arah utara yaitu Merangan Darat hingga arah selatan Mehembat dan Lembonang, kemudian arah timur yaitu Jembayan (Tahangkong) sampai ke arah Jahab. Orang yang pertama kali membuka lahan Silingsing adalah sepasang suami istri yaitu Pak Mi' dan Bu Saerah pada tahun 1948. Keluarga kecil ini menetap selama satu tahun di Selingsing dan pindah kearah selatan yaitu Ukung dan membuka lahan di sana selama 2 tahun. Pada tahun 1952 beberapa bulan tinggal di Jembayan dan melahirkan seorang putra yang diberi nama Ahmad dan sering dipanggil dengan sebutan Mat.

Pada tahun yang sama pasangan ini kembali ke Selingsing dan naik ke darat yaitu wilayah Gunung Kepeng, Munte, dan Guntung Ojot (sekarang wilayah Tudungan) untuk membuka hutan di sana selama puluhan tahun dan banyak melahirkan anak di wilayah itu. Dari keturunan beliau sampai saat ini masih ada yang tinggal di Silingsing hingga cucunya dan sebagian anak yang lain pergi merantau dan menetap di tempat lain seperti Samarinda dan Tanah Grogot.

Pada tahun 60-an berkembanglah Selingsing menjadi sebuah kampung dan para pendatang banyak datang dari suku Kutai Hulu dan Jembayan. Dulu ada suku Kedang Pahu, suku lampung yang sekarang berubah menjadi suku Kutai, kemudian Suku Banjar Negara yang berasal dari
Kampung Tanjung Isyui, namun sangat disayangkan karena begitu luasnya wilayah Jembayan dan terdiri dari beberapa Dusun dan RT. Maka sebagian wilayah tersebut tidak tersentuh sama sekali oleh program yang dimaksud, pembangunan tidak merata banyak terjadi ketimpangan masalah dana. Mengingat hal tersebut di atas maka diadakan rapat LPM Desa Jembayan, dalam agenda musyawarah waktu itu Desa Jembayan ini harus dimekarkan menjadi 3 desa, yaitu Desa Jembayan, Desa Mekar Jaya, Desa Mekar Makmur, dan dari hasil musyawarah tersebut disetujui oleh Bupati Kutai Kartanegara waktu itu Bapak H. Syaukani HR, dan beliau menyarankan agar desa pemekaran tersebut harus memakai nama jembayan sebagai pengingat dulunya bahwa Desa yang dimekarkan ini merupakan bagian dari desa induk, maka disepakati nama desa pemekaran tersebut menjadi Desa Jembayan Tengah dan Desa Jembayan Dalam.

Secara geografis Desa Jembayan Tengah terletak dibagian timur Kabupaten Kutai Kartanegara dengan luas wilayah \pm 4.725 Ha dengan batas sebagai berikut:
a. Wilayah Timur
: Desa Jembayan Induk
b. Wilayah Barat
: Desa Jahab
c. Wilayah Selatan
: Desa Jembayan Dalam
d. Wilayah Utara
: Desa Loh sumber

Desa Jembayan Tengah dilihat secara umum keadaanya merupakan daerah dataran rendah 3,5-8 meter di atas permukaan air laut dengan mayoritasnya merupakan Wilayah tanah tegalan dengan luas 2.000 Hektar, Wilayah Sawah sekitar 200 Hektar. Selebihnya adalah tanah pekarangan dengan luas 15 Hektar. Penduduk Desa Jembayan Tengah sebanyak 1.138 KK yang terdiri dari laki-laki sebanyak 1.768 jiwa $(51,8 \%)$ dan perempuan sebanyak 1.644 jiwa ( 48,2\%) dapat dilihat pada tabel 1 .

Tabel 1. Jumlah Penduduk Desa Jembayan Tengah Berdasarkan Jenis Kelamin

\begin{tabular}{ccc}
\hline $\begin{array}{c}\text { Penduduk dan } \\
\text { Keluarga }\end{array}$ & Jumlah & Persentasi \\
\hline
\end{tabular}

\begin{tabular}{|c|c|c|}
\hline Jumlah & 862 Jiwa & $48,40 \%$ \\
\hline $\begin{array}{l}\text { Penduduk Laki- } \\
\text { laki }\end{array}$ & & \\
\hline Jumlah & 919 Jiwa & $51,60 \%$ \\
\hline Penduduk & & \\
\hline Perempaun & & \\
\hline Total & 1.781 Jiwa & $100,00 \%$ \\
\hline Jumlah Keluarga & $523 \mathrm{KK}$ & \\
\hline
\end{tabular}

Jumlah penduduk berdasarkan suku di Desa Jembayan Tengah menunjukan bahwa suku banjar menduduki jumlah yang dominan yaitu sebesar 40,12\% (684 Jiwa) kemudian suku Bugis sebesar 15,93\% (602 Jiwa) disusul suku kutai 14,42\% (507 Jiwa), dan suku Jawa sebesar 21,80\% (424 Jiwa) dan suku Dayak dan suku lainnya 0,69\% (26 Jiwa). Dari data di atas dapat dilihat bahwa suku banjar memiliki jumlah penduduk 
terbanyak dengan persentase $40,12 \%$ dapat dilihat pada tabel 2 .

Tabel 2. Jumlah Penduduk Desa Jembayan Tengah Berdasarkan Suku

\begin{tabular}{|c|c|c|}
\hline Suku Bangsa & Jumlah & Persentasi \\
\hline 1. Banjar & 683 Jiwa & $48,16 \%$ \\
\hline 2. Bugis & 256 Jiwa & $15,01 \%$ \\
\hline 3. Kutai & 230 Jiwa & $13,49 \%$ \\
\hline 4. Jawa & 211 Jiwa & $12,38 \%$ \\
\hline $\begin{array}{l}\text { 5. Dayak dan } \\
\text { lainnya }\end{array}$ & 156 Jiwa & $10,96 \%$ \\
\hline
\end{tabular}

Tingkat partisipasi pendidikan penduduk di Desa Jembayan Tengah cukup rendah jika dibandingkan di tingkat kabupaten dan nasional. Hal ini dapat dilihat dari jumlah penduduk yang tidak lulus dan tidak sekolah berdasarkan Profil Desa Jembayan Tengah Tahun 2018 dapat dilihat pada tabel 3 .

Tabel 3. Jumlah Penduduk Desa Jembayan Tengah Berdasarkan tingkat pendidikan

\begin{tabular}{lcc}
\hline \multicolumn{1}{c}{$\begin{array}{c}\text { Tingkat } \\
\text { Pendidikan }\end{array}$} & Jumlah & Persentasi \\
\hline $\begin{array}{l}\text { Lulusan S-1 } \\
\text { keatas }\end{array}$ & 3 & $0,48 \%$ \\
Lulusan SLTA & 74 & $11,75 \%$ \\
Lulusan SMP & 127 & $20,16 \%$ \\
Lulusan SD & 253 & $40.16 \%$ \\
Tidak Tamat SD/ & 131 & $20,79 \%$ \\
Tidak Sekolah & & \\
Buta Huruf & 42 & $6,67 \%$ \\
\hline
\end{tabular}

Berdasarkan data profil Desa Jembayan Tengah 2018, pekerjaan/ mata pencaharian penduduk Desa Jembayan Tengah dapat dilihat pada tabel 4.

Tabel 4. Jumlah Penduduk Desa Jembayan Tengah Berdasarkan Pekerjaan/ Mata Pencaharian

\begin{tabular}{|c|c|c|}
\hline $\begin{array}{l}\text { Pekerjaan/Mata } \\
\text { Pencaharian }\end{array}$ & Jumlah & Satuan \\
\hline $\begin{array}{l}\text { 1. Pertanian, } \\
\text { perikanan, } \\
\text { perkebunan }\end{array}$ & 168 & Orang \\
\hline $\begin{array}{l}\text { 2. Pertambangan } \\
\text { dan penggalian }\end{array}$ & 141 & Orang \\
\hline $\begin{array}{l}\text { 3. Industri } \\
\text { pengolahan } \\
\text { (Pabrik, } \\
\text { Kerajinan, dll) }\end{array}$ & 148 & Orang \\
\hline $\begin{array}{l}\text { 4. Perdagangan } \\
\text { besar/eceran } \\
\text { dan Rumah } \\
\text { Makan }\end{array}$ & 31 & Orang \\
\hline 5. Swasta & 148 & Orang \\
\hline 6. Jasa/Tukang & 27 & Orang \\
\hline $\begin{array}{l}\text { 7. Lainnya (air, } \\
\text { gas, listrik, } \\
\text { kontruksi, }\end{array}$ & 16 & Orang \\
\hline
\end{tabular}

\begin{tabular}{llcl}
\hline & perbankan, dll) & & \\
8. & PNS & 3 & Orang \\
9. Guru & 45 & Orang \\
10. Bidan Swasta & 1 & Orang \\
11. Buruh & 240 & Orang \\
\hline
\end{tabular}

B. Potensi Agrowisata Desa Jembayan Tengah

1. Hasil Analisis Potensi Agrowisata menggunakan Konsep 3S

Berbicara tentang potensi objek wisata ada baiknya dikaitkan dengan atraksi wisata yaitu "product" industry pariwisata. Jadi objek dan atraksi wisata itu sendiri sebenarnya sudah termasuk kedalam produk industry pariwisata, karena jika tidak ada produk wisata, maka motivasi untuk berkunjung ke daerah tujuan wisata itu bisa dikatakan tidak ada.

Desa Jembayan Tengah merupaan tempat yang berpotensi sebagai destinasi wisata, dapat ditinjau dari persyaratan tempat yang berpotensi dikunjungi wisatawan yaitu:

a. Something to see

Something to see yang dimaksud yaitu tempat tersebut harus ada yang dilihat dan disaksikan.

b. Something to do

Something to do adalah ditempat tersebut harus ada objek atau atraksi wisata.

c. Something to buy

Something to buy artinya di tempat tersebut harus ada tempat untuk berbelanja. Dapat dilihat pada tabel 5 .

Tabel 5. Tabel Analisis 3S

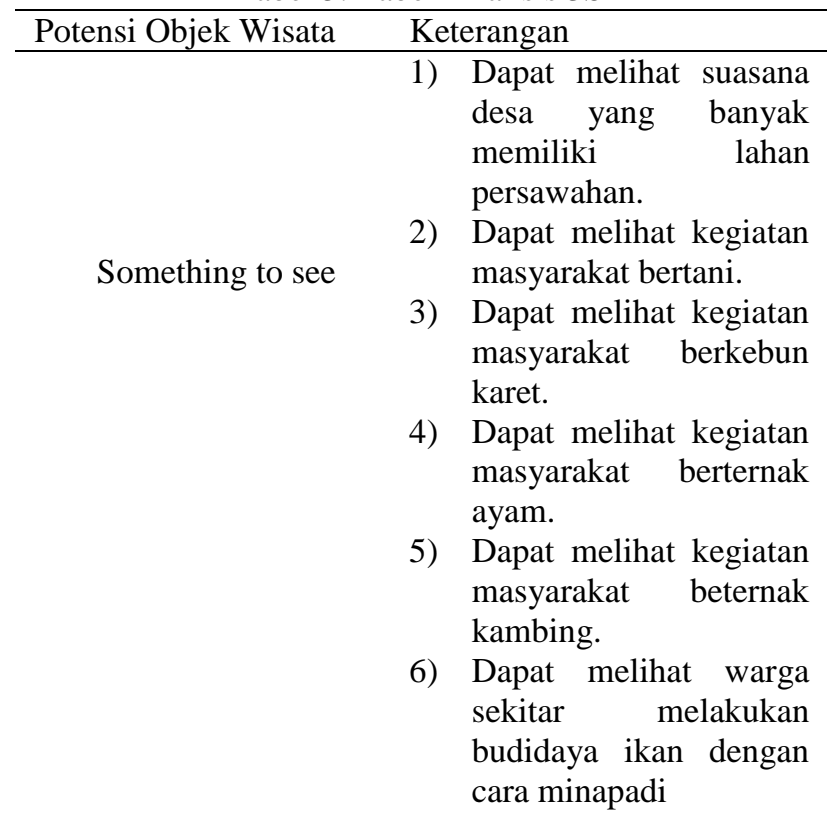

1) Wisatawan mendapatkan materi edukasi tentang agrowisata khususnya materi tentang tanaman padi, pohon karet, serta 
peternakan ayam dan kambing.

2) Wisatawan dapat belajar cara menanam padi secara tradisional.

3) Wisawatawan dapat belajar bagaimana cara memanen padi secara tradisional.

4) Wisatawan dapat ikut serta dalam kegiatan membajak sawah.

5) Wisatawan dapat ikut serta dalam proses penyadapan getah pohon karet.

6) Wisatawan dapat ikut memberi makan ayam ternak.

7) Wisatawan dapat ikut serta memberi makan kambing.

8) Wisatawan dapat belajar bagaimana cara memeras susu kambing.

9) Wisatawan dapat diajak melihat pembuatan pupuk kandang.

10) Wisatawan dapat diajak untuk menangkap ikan.

1) Hasil pertanian di Desa

Something to buy Jembayan Tengah berupa beras dan sayursayuran.

2) Souvernir berupa gantungan kunci berbentuk seraung (ciri khas Desa Jembayan Tengah).

3) makanan berupa Kue kering buatan masyarakat sekitar.

4) Souvernir berupa hiasan lampion yang terbuat dari gelas minuman plastik.

5) Souvernir berupa kerajinan ukir (piala kayu) dari kayu bekas.

2. Hasil Analisis Potensi Agrowisata Menggunakan Konsep 4A (Attraction, Accessibility, Amenity, Anciliary)

Unsur 4A (atraksi, aksebilitas, amenitas, Anciliary) yang terdapat pada Desa Jembayan Tengah dimana unsur 4A ini menjadi sangat penting untuk dimiliki oleh setiap destinasi wisata, karena akan berpengaruh pada tingkat kunjungan wisatawan, lama tinggal wisatawan dan minat wisatawan untuk berkunjung kembali, unsur 4A yang terdapat di Desa Jembayan Tengah Sebagai Berikut:

1) Daya Tarik Agrowisata (Attractions)

Desa Jembayan Tengah terletak di dataran rendah dengan mayoritas penduduk berprofesi sebagai petani, peternak, perkebunan dan perikanan, yang memiliki luas lahan persawahan sekitar 200 Hektar. Sehingga, Desa Jembayan Tengah memiliki potensi untuk dikembangkan menjadi kawasan agrowisata yang merupakan gabungan dari beberapa daya tarik wisata alam,budaya dan buatan Alam memanfaatkan kegiatan pertanian, perkebunan, perikanan dan peternakan sebagai daya tarik wisata, selanjutnya adalah buatan dengan menyediakan lokasi buatan untuk melakukan kegiatan agrowisata serta menggunakan peralatan ataupun pupuk buatan, dan yang terakhir adalah budaya dalam proses bertani, berkebun dan berternak secara tradisional atau cara lama adalah termasuk budaya keseharian penduduk Desa Jembayan Tengah. Hal ini dapat dijadikan sebagai potensi untuk dijadikan daya tarik wisata dalam kategori wisata edukasi yang dapat memberikan ilmu bagi wisatawan.

2) Aksesibilitas (Accessibility)

Untuk menuju Desa Jembayan Tengah belum terdapat petunjuk jalan, selain itu akses yang dapat digunakan adalah transportasi darat, dan harus menggunakan kendaraan pribadi dikarenakan tidak ada kendaraan umum yang menuju desa tersebut. Kondisi jalan untuk menuju Desa Jembayan Tengah sudah cukup baik walaupun ada sedikit jalan berlobang. Desa Jembayan Tengah dapat di tempuh sejauh 19 kilometer dari pusat kota tenggarong dan 45 kilometer dari pusat kota samarinda, atau 1jam 30 menit dari pusat kota samarinda dan 30 menit dari pusat kota tenggarong.

3) Amenitas (amenities)

Fasilitas penunjang yang terdapat di desa jembayan tengah antara lain; listrik dan energy di Desa Jembayan Tengah dapat dikatakan baik atau tidak. Sebab jika Agrowisata benar dikembangkan di Desa ini, agrowisata merupakan objek wisata outdor yang mana kemungkinan listrik tidak di letakan diluar. Namun apabila ada acara yang diadakan di dalam ruangan, sumber listrik dan energy dapat dikatakan baik karena listrik di Desa Jembayan Tengah berfungsi dan mengalir dengan baik. Untuk penginapan wisatawan dapat memanfaatkan rumah warga sekitar sebagai Homestay. Untuk sistem pengairan di Desa Jembayan Tengah berasal dari beberapa sumber antara lain: air hujan, air isi ulang, air sungai/waduk/danau, dan sumur bor. Dan saluran pembuangan air/kotoran berfungsi dengan baik dan tidak ada kebocoran.

Selanjutnya adalah lahan parkir, di depan kantor Desa Jembayan Tengah terdapat halaman yang cukup untuk dijadikan lapangan parkir namun tidak banyak kendaraan yang dapat ditampung dan dibutuhkan lagi lahan tambahan dikarenakan 
halaman kantor desa tidak memuat banyak kendaraan. Fasilitas penunjang selanjutnya adalah masjid, toko souvernir, warung dan posyandu yang dapat dimanfaatkan oleh wisatawan yang datang. Untuk Akses jaringan komunikasi kurang berjalan dengan baik karena hanya kartu operator Telkomsel yang dapat digunakan di desa ini.

4) Ancillary (Pelayanan Tambahan)

a. Kelompok Sadar Wisata (Pokdarwis) Desa Jembayan Tengah.

Setelah melakukan wawancara dengan Kepada Desa Bapak Rahimin, M.Sos. pada tanggal 19 juni 2020, beliau menerangkan bahwa baru saja dibentuk kelompok sadar wisata untuk mempermudah koordinasi untuk pengembangan wisata di Desa Jembayan Tengah.

b. Karang Taruna

Selama ini, karang taruna juga berperan aktif dalam membantu pelaksanaan dan mensukseskan setiap acara-acara yang dilaksanakan di Desa Jembayan Tengah.

c. Pemerintah Desa

pemerintah desa telah berkomitmen dan sepakat dalam mengarahkan pembangunan Desa Jembayan Tengah sebagai Wisata Desa yang menonjolkan seluruh potensi yang ada di Desa Jembayan Tengah. Namun rencana tersebut terkendala oleh pendanaan dan kurangnya informasi mengenai konsep Agrowisatadan tidak ada bimbingan dari Dinas Pariwisata Kukar untuk melakukan pembinaan SDM Desa Jembayan Tengah.

d. Group Kesenian Desa Jembayan Tengah

Kelompok kesenian ini biasa menampilkan kesenian tradisional seperti tarian dan music tradisional seperti tingkilan. Selain tampil di Desa Jembayan Tengah, kelompok kesenian Ini juga turut di undang di berbagai acara yang dilaksanakan di luar Desa Jembayan Tengah.

e. Puskesmas Pembantu (Pusban)

Pusban Desa Jembayan Tengah terdapat di dusun Lempatan yaitu berdekatan dengan Kantor desa. Pusban ini dapat difungsikan sebagai tempat memberikan pertolongan pertama apabila terjadi kecelakaan atau sakit bagi wisatawan dan masyarakat setempat. Namun meilihat kondisi bangunan yang kurang layak pihak desa telah mengajukan permohonan kepada Pemerintah untuk membangun Pusban yang lebih layak, namun hingga saat ini belum di setujui.

Berhasarkan hasil analisis 4A di atas, Desa Jembayan Tengah termasuk desa yang memiliki potensi agrowisata yang cukup kuat. Adapun potensi agrowisata yang terdapat di Desa Jembayan Tengah antara lain:

1) Pertanian

Potensi pertanian sangatlah menjanjikan, didukung oleh letak geografis, faktor iklim dan sebagian besar masyarakat Desa Jembayan Tengah yang bermata pencarian sebagai petani. Selain dijadikan sebagai untuk bercocok tanam, lahan persawahan juga dapat dikembangkan menjadi objek wisata dan menjadi daya tarik wisata yang dapat menarik wisatawan untuk berkunjung.

Potensi di Desa Jembayan Tengah Yang dapat dikembangkan sebagai agrowisata yang pertama adalah pertanian. Pertanian yang terdapat di Desa Jembayan Tengah adalah pertanian padi,adapun kegiatan yang dilakukan antara lain:

a. Melakukan proses kegiatan penanaman padi secara tradisional.

b. Melakukan kegiatan menggarap/pembajakan sawah secara tradisional.

c. Melakukan proses kegiatan pemanenan padi secara tradisional

d. Memandikan hewan pembajak sawah seperti kerbau.

2) Perkebunan Karet

Potensi kedua yang terdapat di Desa Jembayan Tengah adalah Perkebunan Karet dimana kita ketahui bahwa banyak sekali barang-barang yang terbuat dari karet dan tentunya asal usul karet tersebut dapat menjadi nilai edukasi bagi sebagian orang ataupun anak-anak. Adapun kegiatan kegiatan yang dapat dilakukan kepada wisatawan antara lain adalah:

a. Pemberian materi tentang jenis tanaman karet seperti karakteristik tumbuhan karet, manfaat tumbuhan karet, kondisi geografis, waktu dan cara menanam serta memanen yang benar.

b. Wisatawan dapat diajak untuk belajar dan mencoba cara penyadapan getah karet.

3) Peternakan Ayam

Peternakan Ayam tentunya sangat menjanjikan untuk dijadikan suatu usaha. Selain dapat dijadikan usaha tentunya peternakan ayam juga dapat dijadikan sebagai objek wisata sebagai objek untuk memberikan nilai edukasi pengetahuan kepada wisatawan yang berkunjung. adapun yang dapat dilakukan kepada wisatawan antara lain:

a. Pemberian materi edukasi kepada wisatawan seperti memberikan penjelasan tentang jenis-jenis unggas, jenis-jenis ayam, cara beternak ayam yang benar, cara merawat ayam dengan benar dan cara reproduksi ayam.

b. Wisatawan dapat mencoba untuk memberi makan ayam.

c. Membuat olahan makanan terbuat dari daging ayam yang dapat di hidangkan kepada wisatwan.

4) Peternakan Kambing

Usaha peternakan kambing tentunya sangat menguntungkan, dimana masyarakat selalu mencari kambing pada saat perayaan hari raya Idul Adha untuk dijadikan hewan kurban, selain itu juga masyarakat menjadikan kambing sebagai hewan yang di potong saat mengadakan acara aqiqah. Selain itu peternakan kambing juga dapat dijadikan wisata edukasi. Adapun yang dapat dilakukan kepada wisatawan antara lain:

a. Memberikan materi semua tentang hewan kambing yang bernilai edukasi kepada wisatawan 
seperti cara beternak kambing yang benar, cara bereproduksi kambing, jenis makanannya dan sebagainya.

b. Wisatawan dapat diajak memberi makan kambing.

c. Wisatawan dapat diajak untuk memeras susu kambing.

d. Diajak untuk melihat pembuatan pupuk kandang.

e. Membuat olahan makanan daging kambing untuk hidangkan kepada wisatawan.

5) Perikanan

Potensi kelima yang terdapat di Desa Jembayan Tengah yang dapat dimanfaatkan sebagai agrowisata adalah perikanan. Perikanan yang terdapat di Desa Jembayan Tengah adalah perikanan dengan system minapadi, yaitu budidaya ikan dengan cara mengoptimalkan atau memaksimalkan lahan persawahan dengan menggabungkan pertanian padi dengan budidaya ikan adapun manfaat dari perikanan minapadi ini diharapkan meningkatnya produksi ikan secara organik dan ramah lingkungan. Ikan yang dibudidayakan di Desa Jembayan Tengah dengan system minapadi adalah ikan nila. Adapun kegiatan agrowisata yang dapat dilakukan kepada wisatawan adalah:

a. Memberikan materi edukasi kepada wisatawan tentang budidaya ikan dengan system minapadi.

b. Wisatawan diajak untuk menangkap ikan dan hasil tangkapannya dapat mereka bawa pulang ataupun diolah untuk konsumsi di tempat.

6) Kemiri dan Jahe

Potensi agrowisata selanjutnya yang terdapat di desa jembayan tengah adalah Kemiri dan jahe. Dalam hal ini kemiri dan jahe tidak diikutkan kepada kegiatan edukasi agrowisata namun potensi ini dapat dimanfaatkan sebagai produk dari Desa Jembayan Tengah guna memaksimalkan Potensi yang ada seperti:

a. Pengolahan kemiri menjadi bubuk lalu dikemas sedemikian rupa dan mencantumkan tulisan Jembayan Tengah pada kemasan sebagai brandingnya dan hasilnya dapat dijual kepada wisatawan yang datang.

b. Pengolahan jahe menjadi produk seperti jamu, ice cream lalu dikemas dan mencantumkan tulisan Jembayan Tengah sebagai brandingnya dan dapat dijual kepada wisatawan.

7) Singkong Selingkuh

potensi agrowisata yang terakhir adalah singkong selingkuh. Singkong selingkuh merupakan jenis singkong pada umumnya hanya saja singkong ini memiliki ukuran yang tidak wajar yaitu sebesar paha orang dewasa. Singkong ini dapat dijadikan sebagai daya tarik wisata kepada wisatawan yang berkunjung. Adapun kegiatan yang dapat dilakukan wisatawan adalah mencoba memanen atau mencabut singkong di kebunnya langsung. Selain itu singkong ini juga dapat dimanfaat untuk membuat tepung atau olahan makanan tradisional seperti getuk yang akan disajikan kepada wisatawan yang datang.
3. Konsep Pengembangan Agrowisata di Desa Jembayan Tengah

Dalam pengembangan agrowisata diharapkan Desa Jembayan Tengah memperhatikan beberapa aspek penting dalam pengembangan agrowisata, meliputi:

a. Tetap mempertahankan keaslian ekosistem dengan mengupayakan kelestarian sumber daya alam dengan membagi zonasi agar aktifitas wisata tidak merusak atau menggangu kegiatan pertanian, perkebunan, perikanan dan peternakan yang sebenarnya dan menjaga keamanan wisatawan dari berbagai ancaman seperti binatang buas, bencana alam dan situs berbahaya.

b. Melakukan pembinaan kepada masyarakat untuk menambah keahlian SDM untuk mengelola dan mengembangkan potensi yang menjadi suatu nilai tambah baik dari penyerapan hasil pertanian maupun dari kunjungan wisatwan.

c. Inventaris kekuatan agrowisata

d. Menjalin kerjasama dengan dinas pariwisata dan lembaga pertanian dalam pembinaan tentang agrowisata serta menjalin kerjasama dengan pihak akademisi seperti Polnes Jurusan Pariwisata untuk memberikan pelatihan kepemanduan wisata khusus agrowisata.

e. Aspek keuangan, dalam pengembangan dibutuhkan modal yang cukup besar maka dari itu diharapkan pihak Desa Jembayan Tengah dapat menjalin kerjasama dengan pemerintah ataupun pihak swasta untuk mencari CSR.

f. Melengkapi fasilitas sarana dan prasarana dimana kelengkapan itu sangat berpengaruh kepada tingkat kenyamanan wisatawan pada saat berkunjung. Fasilitas yang dapat di kembangkan dalam lokasi agrowisata antara lain : gerbang pintu masuk, parkir di dalam lokasi, pos keamanan, tempat sampah, masjid/ mushola, kamar mandi/ toilet, rumah makan /restaurant, wartel, shelter, toko cineramata, pusat informasi, kendaraan selama berada di lokasi seperti sepeda, jalan setapak, gardu pandang, brosur/ guide book, petunjuk arah, loket karcis, pramuwisata/ Guide, pos P3K, ambulance, kantor pengelola.

g. Pemilihan lokasi agrowisata, dimana Desa Jembayan Tengah merupakan daratan rendah karakteristik alam seperti ini dapat digunakan untuk agrowisata peternakan, perkebunan, pertanian dan perkanan. Akan lebih menarik jika menciptakan daya tarik tambahan seperti mengadakan kegiatan event pariwisata seperti festival dengan menonjolkan hasil pertanian dan mengadakan karapan sapi atau kerbau sebagai daya tarik kepada wisatwan.

h. Melakukan Pengembangan dengan model lanskap untuk memanfaatkan dan melestarikan kawasan lindung setempat serta mengembangkan kawasan budi daya pertanian untuk menunjang keindahan alam. 


\section{KESIMPULAN}

Berdasarkan dari hasil penelitian dan analisis yang telah dilakukan dapat diambil kesimpulan:

Penelitian ini adalah untuk menentukan potensi-potensi yang ada di Desa Jembayan Tengah, baik itu potensi wisata alam, budaya. Hasil pertanian yang dimiliki oleh Desa Jembayan Tengah dapat dijadikan agrowisata, di mana wisata yang melibatkan pengunjung ikut ikut ambil bagian dari kehidupan para petani.

Desa Jembayan Tengah Kecamatan Loa Kulu Kabupaten Kutai Kartanegara sangat layak untuk dilakukan pengembangan sehingga menjadi tempat obyek dan daya tarik wisata di wilayah Kabupaten Kutai Kartanegara.

\section{DAFTAR PUSTAKA}

Ayu, I. K. (2020). Mengembangkan Potensi Desa Bringin Menjadi Desa Wisata. Jurnal Pembelajaran Pemberdayaan Masyarakat (JP2M), Volume 1, 15.

https://doi.org/http://dx.doi.org/10.33474/jp2m.v1i1 .4992

Chairunnisa, L. Sari, W. E. Arifin, D. (2020). Sistem Informasi Geografis Pemetaan Tempat Wisata di Kota Samarinda Berbasis Web. Buletin Poltanesa, Volume 21, 18-25. https://doi.org/https://doi.org/10.51967/tanesa.v21i 1.320

Ghani, Y. A. (2017). Pengembangan Sarana Prasarana Destinasi Pariwisata Berbasis Budaya di Jawa Barat. Jurnal Pariwisata, 4 (2), 22-31. https://ejournal.bsi.ac.id/ejurnal/index.php/jp/article /view/1798

Ingkadijaya, R., Ratu Bilqis, L. D. (2020). Peningkatan Kapasitas Kelompok Penggerak Pariwisata dalam Pengelolaan Desa Wisata Berkelanjutan di Desa Cipasung, Kabupaten Kuningan. Jurnal Pemberdayaan Pariwisata, 2 (2), 89-96. http://jurnalpariwisata.stptrisakti.ac.id/index.php/JP $\mathrm{P} /$ article/view/1436/211

Mahriani, E. (2020). Manajemen Pariwisata (Sebuah Tinjauan Teori dan Praktis). In Moh Agus Sutiarso (Ed.), Pariwisata yang mengglobal dan menjanjikan (Pertama, p. 1). Widina Bhakti Persada Bandung. www.penerbitwidina.com

Pantiyasa, I. W. (2018). Strategi Pengembangan Potensi Desa Menjadi Desa Wisata di Kabupaten Tabanan (Studi Kasus Desa Tegal Linggah, Penebel, Tabanan). Jurnal Ilmiah Hospitality Management, 4(1), 1-28. https://doi.org/https://doi.org/10.22334/jihm.v4i1.4 8

Sembiring, V. A., Taviprawati, E., Darsiah, A. (2020). Pengembangan Potensi Desa WisataMelalui Pelatihan Homestay di Desa Cipasung, Kuningan. Jurnal Pemberdayaan Pariwisata, 2 (1), 1-10. http://jurnalpariwisata.stptrisakti.ac.id/index.php/JP $\mathrm{P} /$ article/view/1364/177

Sembiring, V. A., Widyastuti, N., Mustika, A. (2019). Pengembangan Potensi Desa Wisata Melalui
Pelatihan Pengenalan Homestay di desa Sungsang Iv, Kabupaten Banyuasin, Sumatra Selatan. Jurnal Pemberdayaan Pariwisata, $\quad 1 \quad(1), \quad 1-8$. http://jurnalpariwisata.stptrisakti.ac.id/index.php/JP $\mathrm{P} /$ article/view/1322/160

Srisusilawati, P. (2020). Manajemen Pariwisata (Sebuah Tinjauan Teori dan Praktis). In Moh Agus Sutiarso (Ed.), Pemasaran bisnis pariwisata di era digital (Pertama, p. 43). Widina Bhakti Persada Bandung. www.penerbitwidina.com

Suawantoro, G. (1997). Dasar-dasar Pariwisata. Penerbit Andi.

Suprina, R., Pasaribu, P., Rachmatullah, A. (2020). Penguatan Organisasi Pokdarwis di Desa Muntei, Desa Madobag dan Desa Matotonan di Pulau Siberut, Kabupaten Mentawai. Jurnal Pemberdayaan Pariwisata, 2 (2), 104-110. http://jurnalpariwisata.stptrisakti.ac.id/index.php/JP $\mathrm{P} /$ article/view/1450/216

Susyanti, D. W., \& Latianingsih, N. (2015). Potensi Desa Melalui Pariwisata Pedesaan. Epigram, Volume 11, 65-70.

https://doi.org/https://doi.org/10.32722/epi.v11i1.6 66

Tirtawinata, R., F. (1996). Daya Tarik dan Pengelolaan Agrowisata. Penebar Swadaya.

Yoeti, O. K. (1996). Pengantar Ilmu Pariwisata. Penerbit Angkasa. 